\title{
The floristic relationship between the upland and lowland Carboniferous wetlands of Variscan Euramerica - Evidence from some medullosalean pteridosperm fronds
}

\author{
Christopher J. Cleal ${ }^{1 *}$ (iD and Borja Cascales-Miñana ${ }^{2}$
}

\begin{abstract}
Alethopteris grandinii represents remains of fronds of a medullosalean pteridosperm (probably a small tree) that rapidly migrated across the lowland wetland habitats of Variscan Euramerica in middle Asturian (late Moscovian) times. This was probably caused by changing drainage patterns within the lowland coal swamps, in response to climate and landscape changes. However, these medullosaleans had first appeared rather earlier, in early Bolsovian (early Moscovian) times, in upland wetland habitats. These upland habitats may have pre-adapted these plants to the changed condition in the lowland coal swamps.
\end{abstract}

Keywords: Carboniferous, Coal swamps, Medullosales, Upland, Migration

\section{Introduction}

During Pennsylvanian (late Carboniferous) times, large parts of palaeotropical Euramerica were covered by wetlands, often referred to as coal swamps because of the extensive coal deposits that were formed from their peats. These heavily vegetated wetlands consisted of a complex of clastic and peat substrates habitats formed in a fluvio-lacustrine setting. During most of Westphalian (late Bashkirian to late Moscovian) times, the vegetation tended to be dominated by arborescent lycopsids, with subsidiary ferns, sphenophytes, and pteridospermous and cordaitean gymnosperms; later in Westphalian and Stephanian (latest Moscovian to Gzhelian) times, marattialean ferns and alethopterid medullosaleans became the dominant plants.

Although at any one time the general character of the coal swamp vegetation was broadly similar across Euramerica, some palaeobiogeographical variation has been recognised, especially between the paralic lowland areas and the intra-montane basins (Gothan 1915, 1925, 1951, 1954; Thomas 2007; Cleal 2008a, 2008b; Cleal et al.

\footnotetext{
* Correspondence: chris.cleal@museumwales.ac.uk

'Department of Natural Sciences, National Museum Wales, Cardiff CF10 3NP, UK

Full list of author information is available at the end of the article
}

2010a; Fig. 1). We now believe that these floristic differences provide important insights into how the coal swamp vegetation evolved during Pennsylvanian times, especially in response to the landscape and climate changes occurring at this time (Gastaldo et al. 1996; Cleal and Thomas 1999, 2005; Opluštil and Cleal 2007; Cleal et al. 2010a, 2011).

In this paper we examine evidence for the migration of vegetation from upland to lowland wetland habitats during late Moscovian times, with particular reference to the Saar-Lorraine Basin that straddles the border between France and Germany (Schindler and Heidtke 2007). This basin formed in a half-graben between the Rheno-Hercynian and Saxo-Thuringian zones of the Variscan Orogen (Kneuper 1964, 1966; Korsch and Schäfer 1995; Schäfer and Korsch 1998) and is one of the best documented of the Westphalian age intramontane basins, with an Upper Paleozoic sedimentary fill of c. $10 \mathrm{~km}$ thickness. We will be focussing in particular on a group of medullosalean pteridosperms that bore fronds of the fossil-genus Alethopteris von Sternberg, which in late Moscovian and Kasimovian times was a major component of the Euramerican wetland vegetation; in the lowland paralic basins, its appearance was part of a major vegetational change represented by the base of the Crenulopteris acadica Zone, formerly known as the Lobatopteris 


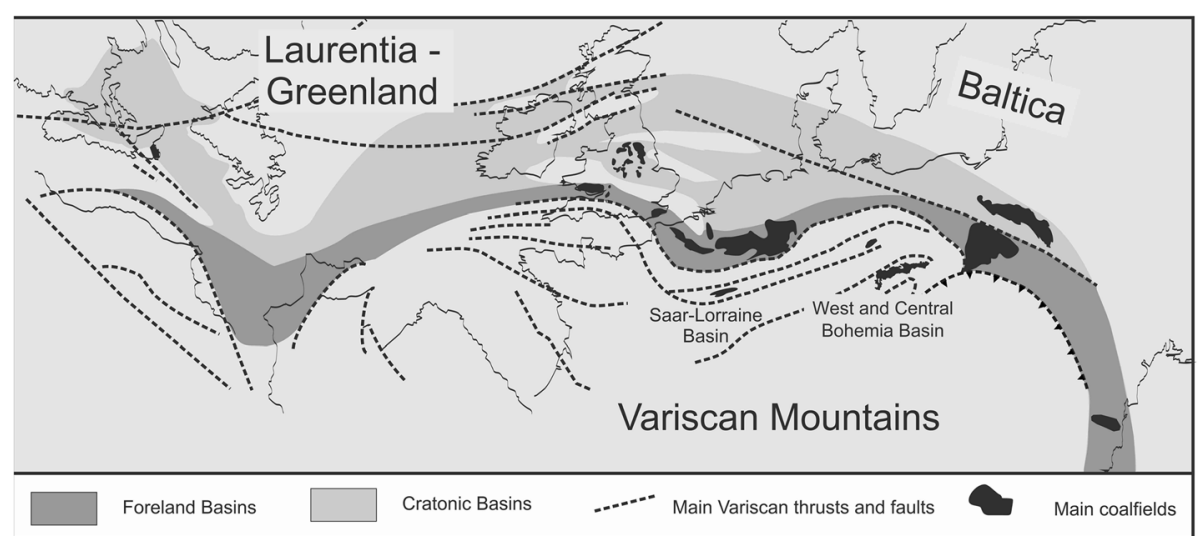

Fig. 1 Palaeogeographical map of Variscan Euramerica during middle Westphalian times, showing large area of paralic coal swamps and the two main intramontane basins, Saar-Lorraine and West and Central Bohemia. Adapted with permission from Cleal et al. (2010a, their Fig. 1)

vestita Zone (Wagner 1984; Cleal 1991). However, we will show that there is evidence that these plants were present rather earlier in the upland wetlands such as the Saar-Lorraine Basin.

We will limit our discussion to the evidence available in the area of palaeotropical coal swamps between the Acadian Mountains (Pfefferkorn and Gillespie 1980) in the west, which approximates in position to the modern-day Appalachian Mountains, and the Palaeotethys Ocean in the east. This area has been named Variscan Euramerica (Cleal et al. 2010a) and at least during early Bashkirian to middle Moscovian time represented the largest area of coal swamps in Euramerica (Cleal and Thomas 2005). There are extensive adpression floras known from coal swamp habitats west of the Acadian Mountains (e.g. Pfefferkorn and Gillespie 1980; Blake et al. 2002) but their taxonomy and biostratigraphy have not been investigated in detail in recent years, making a comparison with the data from the more easterly basins difficult. We will hereafter use the Heerlen Regional Chronostratigraphy, as reviewed by (Wagner 1974) and Wagner and Winkler Prins (2016) as this still provides a far better temporal resolution of the terrestrial coal-bearing sequences of Variscan Euramerica; for a correlation between this scheme and the IUGS Global Chronostratigraphy based mainly on marine stratotypes, see Fig. 2. This will include the use of the name Asturian for what was traditionally referred to as the Westphalian D Substage (Wagner et al. 2002). For biostratigraphy, we will use the scheme developed by Wagner (1984) and modified by Cleal (1991) and Cleal and Thomas (1994); see also Fig. 2.

\section{What were the upland wetlands?}

Thomas and Cleal (2017) recently discussed what palaeobotanists have meant in the past when using the term upland floras. It became clear that most so-called upland floras were not upland in any meaningful sense; the term was instead mainly being used to refer to vegetation of dryland or better drained lowland habitats. There is nevertheless evidence of some truly upland Westphalian vegetation in Variscan Euramerica, in the intra-montane basins of the orogen. The elevation of these basins relative to the paralic areas has been the subject of debate. Based on the distinctive nature of the vegetation, Holub et al. (1977) and Tenchov (1976, 1977) estimated elevations of $1000-2000 \mathrm{~m}$ above sea level, whilst Becq-Giraudon and Van Den Driessche (1994) and Becq-Giraudon et al. (1996) interpreted deposits in the Autunian basins of Central France as periglacial, from which they suggested elevations of $4000-5000 \mathrm{~m}$ above sea-level based. More recently, by modelling drainage patterns within the West and Central Bohemia Basin and comparing its palaeogeographical position relative to the foreland basins to the north, Opluštil (2005) estimated it formed at an elevation of about $1000 \mathrm{~m}$.

\section{Stratigraphical correlation}

A difficulty with trying to compare the vegetation dynamics of upland intramontane and lowland paralic basins is stratigraphical correlation. In the paralic basins, marine bands resulting from eustatic flooding have provided what are in effect time-lines that allow accurate correlation (e.g. Bless and Winkler Prins 1972; Bless et al. 1972, 1977) but these are absent from the intra-montane basins. Until relatively recently, macrofloral and palynological biostratigraphy have been the main alternative means of correlation, but using these correlations to compare the vegetation dynamics in the two types of area clearly has the potential to introduce circular arguments. Correlations independent of biostratigraphy have been mainly based around ash bands, often termed tonsteins. Initially this was based around the simple lithostratigraphical correlation of the tonsteins 


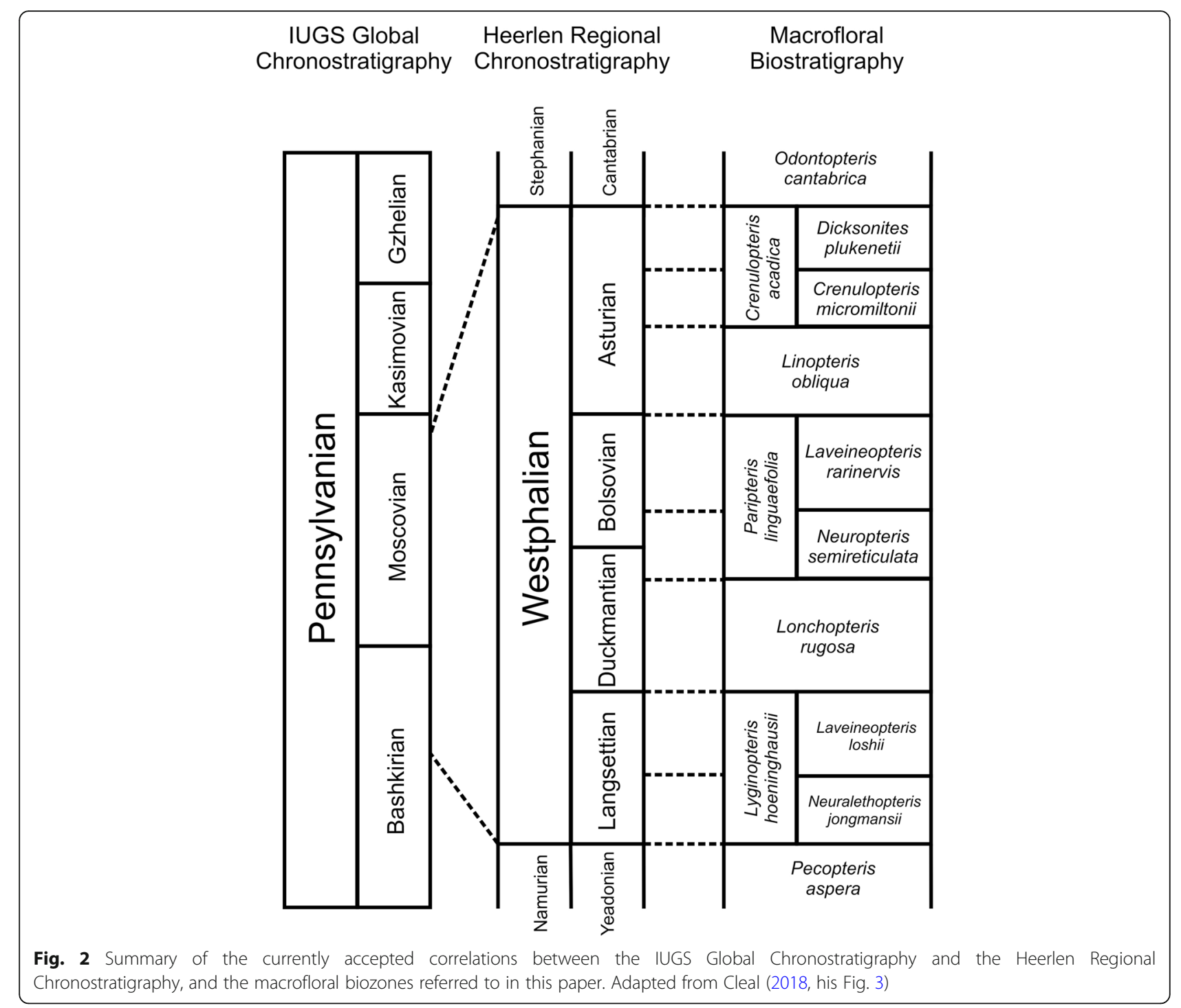

between different basins and this was used to establish a detailed correlation between the intra-montane SaarLorraine and paralic Nord-Pas-de-Calais sequences (Bouroz 1967). More recently, high resolution radiometric dating has further improved the correlations with the West and Central Bohemia Basin (Opluštil et al. 2016) but similar work has yet to be done in Saar-Lorraine Basin.

\section{Major changes in coal swamp floras of Variscan Euramerica}

Plant species diversity fluctuated in the coal swamp vegetation in different basins of Variscan Euramerica in response to a combination of landscape and climate change (Cleal 2005, 2007, 2008c; Uhl and Cleal 2010; Cleal et al. 2010a, 2011, 2012). However, one floristic change stands out as representing a more fundamental reconfiguration of the vegetation, in late Westphalian times. This was probably related to the shift from lycopsid- to fern-dominated vegetation that occurred in the peat-substrate habitats of Variscan Euramerica at this time (Gastaldo et al. 1996; Cleal and Thomas 1999, 2005; Opluštil and Cleal 2007; Cleal et al. 2010a, 2011). However, there was also a marked change in the clastic substrate vegetation reflected in the base of the Crenulopteris acadica Zone (formerly the Lobatopteris vestita Zone) in the Wagner (1984) and Cleal (1991) biostratigraphical scheme. As with the peat substrate vegetation, there is a marked increase in abundance and diversity of marattialean ferns (e.g. Crenulopteris Wittry et al., Cyathocarpus Weiss, Acitheca Schinmper; e.g. Zodrow 1990; Zodrow et al. 2006; Wittry et al. 2015). However, this is also accompanied by an increase in abundance and diversity of medullosalean pteridosperm remains, notably of Alethopteris von Sternberg (e.g. Cleal 1978, 1984, 2007; Zodrow and Cleal 1998; Cleal et al. 2010a, 2010b, 2012). 
The rest of this paper will focus on a distinctive group of alethopterid fronds that have slender pinnules, and which appear abundantly at this floral change. They occur in both lowland and intra-montane basins, albeit recorded under different species names.

\section{Taxonomic notes}

The following is not intended as a detailed taxonomic analysis of these fronds. However, it is critical that we explain exactly how we are using these taxonomic names for understanding the floristics of these plants and their fossils, and therefore the palaeogeographical relationships of these basins. Where comments on the occurrences of the two taxa being discussed are not referenced, they are based on our observations on the Saarbrücken Mining School and University of Lille collections (specimens from the latter have the prefix USTL).

\subsection{Alethopteris grandinii (Brongniart) Göppert, nov. emend. Cleal and Cascales-Miñana, 2019 (Fig. 3)}

\subsubsection{Lectoype}

Specimen MNHN.F.555, Muséum d'Histoire Naturelle, Paris; Locality: Geislautern, near Völklingen, Saarland, Germany; Horizon: upper Heiligenwald Formation (upper Asturian Substage). Designated by Wagner (1968, p. 66). Figured by Brongniart (1833, pl. 91, Fig. 2); photographically refigured by Bertrand (1932, pl. 43, Fig. 2) and Wagner (1968, pl. 17, Fig. 47).

\subsubsection{Synonyms}

Alethopteris ambigua Lesquereux, 1879 pars. emend. Wagner, 1968; Alethopteris pseudoaquilina Potonié, 1893; Alethopteris friedelii Bertrand, 1932; Alethopteris lesquereuxii Wagner, 1968.

\subsubsection{Diagnosis}

Pinnules elongate and parallel sided or sometimes barrel-shaped, except in distal part of pinna where they become slightly subtriangular, with rounded or slightly bluntly acuminate apex; pinnules $8-17 \mathrm{~mm}$ long, 3-8 $\mathrm{mm}$ wide. Pinnule insertion usually at about right-angles. Midvein well developed and extending for most of pinnule length. Lateral veins simple, or once or twice forked at a narrow angle, usually thickly marked, and meet pinnule margin at about right-angles; marginal nervation density normally distributed, range is from 28 to 43 per $\mathrm{cm}$ at pinnule margin with mean $\pm \mathrm{std} .=36 \pm$ 3. Terminal pinnule slender, parallel-sided or slightly tapered, and poorly individualised. Adaxial epidermal cells polygonal, slightly elongate along veins but isodiametric between veins. Abaxial intercostal cells with strongly undulate walls. Stomata irregularly orientated and overarched by ring of prominent papillae. Trichomes sparsely but evenly distributed over most of abaxial surface, more concentrated along pinnule margin.

Based on the emended diagnosis given by Zodrow and Cleal (1998) for Alethopteris ambigua.

\subsubsection{Remark}

Brongniart (1833) described Pecopteris grandinii Brongniart and Pecopteris aquilina Schlotheim ex Brongniart from Geislautern near Völklingen in Saarland Alethopteris. According to Bertrand (1932) this flora was from the formation then known as Flambants supérieurs, now referred to as the upper Heiligenwald Formation, and thus in the upper Asturian Substage (Laveine 1977; Cleal 1984). The types of these species have been subsequently refigured photographically by Bertrand (1932, pls. 36, 37, 43) and Wagner (1968, pl. 17, Figs. 47, 48). Both species were subsequently transferred to Alethopteris von Sternberg, 1825 by Göppert (1836).

It has been widely recognised that the specimens described by Brongniart (1833) as Pecopteris aquilina were different from those originally described as Filicites aquilinus by Schlotheim (1820); even Brongniart (1833) had expressed some doubt on this point. As a consequence, alternative homotypic synonyms Alethopteris pseudoaquilina Potonié, 1893 and Alethopteris friedelii Bertrand, 1932 have been proposed for A. aquilina Schlotheim ex Brongniart non Schlotheim. For a further discussion on this see Wagner (1968, p. 34).

Both elongate and squat pinnule forms described by Brongniart (1833) have very similar venation patterns: the midvein is usually thick and extending for most of the pinnule length, and thick lateral veins that are simple, or once or twice forked; the marginal vein density is usually about 35 per $\mathrm{cm}$. Most authors have continued to keep them as separate taxa although the detailed criteria for distinguishing them have not been clearly established. As shown by Zodrow and Cleal (1998, p. 105) the pinnules in Alethopteris have a predominantly apical development which results in relatively constant pinnule widths but highly variable length:breadth ratios. Squat or elongate pinnule form on its own is therefore unlikely to be a reliable taxonomic indicator.

Bertrand (1932) was clearly aware of the difficulties. Of Brongniart's (1833) A. grandinii syntypes, Bertrand reported one was lost (Brongniart 1833, pl. 91, Fig. 1) and two others (Ibid., pl. 91, Figs. 3, 4) he transferred to his A. friedelii. The fourth syntype (Brongniart 1833, pl. 91, Fig. 2; refigured Bertrand 1932, pl. 43, Fig. 2) is poorly preserved and Bertrand also found this difficult to distinguish from what he called A. friedelii. He commented that, based on the syntypes alone, it would be difficult to justify separating $A$. grandinii from $A$. friedelii and that he had been unable to find any new specimens that he could attribute to $A$. 



Fig. 3 Alethopteris grandinii (Brongniart) Göppert var. grandinii. a - Squat pinnule form; Radstock Formation (Asturian Substage), Radstock, Somerset, UK (BGS Kidst. 3850); b - Slender pinnule form; Heinrich Seam, Heiligenwald Formation (Asturian Substage), Wendel, Saarland, (USTL 3190); c Close-up of typical pinnule form showing coarse veining; Heiligenwald Formation (Asturian Substage), Stocken Borehole (depth $1005.8 \mathrm{~m}$ ), Saarland, (USTL 3191); d - Close-up of more slender pinnule form; Heiligenwald Formation (Asturian Substage), Stocken Borehole (depth 1005.0 m), Saarland, (USTL 3192). Scale bars $=10 \mathrm{~mm}(\mathrm{a}, \mathrm{b}) ; 5 \mathrm{~mm}(\mathbf{c}, \mathbf{d})$

grandinii as he was interpreting it; this corroborates our experience that the squat-pinnule forms are relatively rare compared with the elongate pinnules forms.

Nevertheless, Bertrand (1932) continued to recognise $A$. grandinii as a distinct species from his $A$. friedelii, based mainly on a fifth specimen in the Brongniart collection, also from the Geislautern locality, which he (Bertrand) designated as a "cotype" (figured Bertrand 1932, pl. 43, Fig. 4; pl. 43 bis). This shows relatively squat, basally confluent pinnules with a midvein that does not extend to the pinnule apex, and thus agrees with the emended diagnosis given by Bertrand (1932, p. 76) for A. grandinii. As pointed out by Bertrand, however, the specimen is from the distal part of a penultimate pinna in the transition area between pinnules and ultimate pinnae, where the latter would be expected to have atypically squat pinnules of this type. Since it was reportedly associated with specimens showing the elongate types of pinnule used to characterise A. friedelii, it is difficult to see the justification for establishing a separate species on this specimen alone. 



Fig. 4 Left shows the sizes of pinnules in an assemblage originally identified as Alethopteris ambigua (now referred to A. grandinii) from the Asturian Hub Seam of the Sydney Coalfield (originally documented by Zodrow and Cleal 1998). Right shows the sizes of the types of Pecopteris aquilina and P. grandinii from Geislautern, Saarland, plotted in the same dimension space; also of the types of Alethopteris ambigua and A. lesquereuxii

Bertrand compared a sixth specimen, this time from "Saarbrücken", with A. grandinii (Bertrand 1932, pl. 43, Fig. 3; pl. 44). Although some of the pinnules correspond to Bertrand's emended diagnosis for $A$. grandinii, he noted that the apical pinnules are very similar to those seen in $A$. friedelii. Bertrand was clearly uncertain as to the identity of this specimen, which he named Alethopteris cf. grandinii. A seventh specimen, this time from a much older stratigraphical level at Dudweiler (Bertrand 1932, pl. 45) was described as similar to A. grandinii, but sufficiently distinct to be assigned to a separate variety; this will be discussed later.

In conclusion, we can find little justification for taxonomically distinguishing the types of $A$. grandinii and A. fiedelii. This moreover is in agreement with our observations on the extensive collections of this type of alethopterid in the collections of the Saarbrücken Mining School and University of Lille, where both pinnule forms almost invariably occur in close association. In our view, $A$. grandinii and $A$. friedelii should be regarded as heterotypic synonyms, of which $A$. grandinii is the earlier published name.

In Saar-Lorraine Basin, these frond fragments with the distinctive $A$. grandinii venation appear at about the stratigraphical level of the ash band Tonstein 60 in the upper Heiligenwald/La Houve Formation (Laveine
1977; Cleal 1984). This coincides with the base of the Crenulopteris acadica (Lobatopteris vestita auct.) Zone of Wagner (1984) in the middle Asturian Substage. Morphologically very similar pinna remains occur in the more lowland and paralic basins of northern Spain, southern Britain and the Canadian Maritimes (Wagner 1968; Cleal 1978, 2007; Thomas and Cleal, 1994; Zodrow and Cleal, 1998) usually recorded as Alethopteris ambigua Lesquereux pars. emend. Wagner, 1968 or Alethopteris lesquereuxii Wagner, 1968 (the latter two species were argued to be conspecific with one another by Zodrow and Cleal, 1998). A. grandinii and A. ambigua also have essentially indistinguishable epidermal structures, the former having been described by Barthel (1962) and the latter by Zodrow and Cleal (1998); Barthel (1962) incorrectly used the name Alethopteris davreuxii (Brongniart) Göppert for these fossils, but this refers to a rather different, Duckmantian to Bolsovian species with rather larger pinnules and often a pseudoanastomosed venation (see Buisine 1961). Wagner (1968) in fact argued that A. ambigua is conspecific with $A$. friedelii, using the former name as this had priority. However, if we accept $A$. grandinii as also being conspecific with $A$. ambigua, then the former must take priority over $A$. friedelii as well.

To further corroborate the similarity of these species, Fig. 4 shows a graphical plot of the range of 
pinnule sizes found in an assemblage of fossils associated with the Hub Seam in the Sydney Coalfield, Cape Breton, Canada, based on data reported in Zodrow and Cleal (1998). This is accompanied by a plot of the sizes of the types of A. grandinii, A. friedelii and A. ambigua (also of Alethopteris lesquereuxii Wagner) on the same dimension space. The only one of these types that does not lie within this dimension space is one of the A. grandinii types, which is a little longer but of similar width. However, given the apical development pattern of alethopterid pinnules, this may be of little significance and just regarded as an extreme outlier of the normal range of morphological variation. Since these types all have essentially the same venation patterns, we suggest that they merely represent variation in pinnule shape within the frond of one biological species.

\subsubsection{Occurrences}

Saarland, upper Heiligenwald Formation: Flöz Beust (Luisenthal, Viktoria and Gerhardt Mines), Flöz Elisabeth (Göttelborn Mine), Flöz Constanze (Luisenthal; Bertrand 1932), Borehole Saarbrücken Süd 1 (depth $1091.3 \mathrm{~m}$ ), Borehole Bisten 4 (depth $1169.3 \mathrm{~m}$ ), Borehole Marienau 1 (depth $944.8 \mathrm{~m}$ ), Borehole Marienau 2 (depths $800.5 \mathrm{~m}, 843.0 \mathrm{~m}, 1032.3 \mathrm{~m}$ and $1035.6 \mathrm{~m}$ ), Borehole Marienau 4 (depths 850.5 m, 942.5 m, 990.3 $\mathrm{m}, 990.5 \mathrm{~m}, 991.4 \mathrm{~m}$ and $991.7 \mathrm{~m}$ ), Borehole Pfaffenkopf (depths $76 \mathrm{~m}$ and $116 \mathrm{~m}$ ) and Borehole Stocken (depths $733.3 \mathrm{~m}, 733.5 \mathrm{~m}, 734.3 \mathrm{~m}, 998.5 \mathrm{~m}, 1005.0 \mathrm{~m}$, $1005.8 \mathrm{~m}$ and $1006.8 \mathrm{~m}$ ); also from an uncertain stratigraphical horizon at Geislautern (Bertrand 1932). Lorraine, upper "Assise" Flambants: Veine François (La Houve; Bertrand 1932), Borehole Cocheren 11 (depths $1217.9 \mathrm{~m}$ and $1217.9 \mathrm{~m}$ ), Borehole Cocheren 8 (depth $991.9 \mathrm{~m}$ ), Borehole Cocheren 9 (depth 1133.5 $\mathrm{m})$, Borehole Créhange 1 (depths $1499.0 \mathrm{~m}$ and $1501.3 \mathrm{~m}$ ), Borehole Folschuillerd (depth $1008.5 \mathrm{~m}$ ), Borehole St Fontaine 1 (depths $369.2 \mathrm{~m}$ and $394.7 \mathrm{~m}$ ) and Borehole St Fontaine 4 (depths $572.0 \mathrm{~m}$ and $833.6 \mathrm{~m}$ ). Sydney Coalfield, Cape Breton: between Mullins and Point Aconi seams (upper Morien Group; Zodrow and Cleal 1998). British Isles, upper Warwickshire Group, notably South Wales (Swansea $2 \mathrm{ft}$. to Coalbrook seams; Cleal 2007), Radstock and Pennines Basins (Cleal 2018). Northern Spain: numerous localities in Palencia and León (Wagner 1968). Zonguldak-Amasra Basin, Northeast Turkey (Jongmans 1955; identifications verified by CJC). USA: Mazon Creek (Wittry 2006), Missouri and Pennsylvania (Wagner 1968; exact relationship of these floras to the European regional chronostratigraphy at present uncertain).
5.2 Alethopteris grandinii (Brongniart) Göppert var. duboisii Bertrand nov. emend. Cleal and Cascales-Miñana, 2019 (Fig. 5)

\subsubsection{Lectoype}

Specimen 1874, Benecke Collection, Musée de Géologie, Université l'Strasbourg; Locality: Gegenortesschacht, Dudweiler, Saarbrücken; Horizon: Sulzbach Formation ("Charbons gras" - Bolsovian Substage). Figured by Bertrand (1932, pl. 45).

\subsubsection{Emended diagnosis}

Pinnules elongate and parallel sided or sometimes barrel-shaped, except in distal part of pinna where they become slightly subtriangular, with rounded or slightly bluntly acuminate apex; pinnules $4-20 \mathrm{~mm}$ long, 2-3 $\mathrm{mm}$ wide. Pinnule insertion usually at about right-angles. Midvein well developed and extending for most of pinnule length. Lateral veins simple, or once or twice, usually thinly marked, forked at a wide angle, sometimes tending to flexuous, and meet pinnule margin at about right-angles; marginal nervation density mainly between 35 and 45 per $\mathrm{cm}$. Terminal pinnule slender, parallel-sided or slightly tapered, and poorly individualised.

\subsubsection{Remark}

In most basins in Variscan Euramerica, A. grandinii first appears in the middle Asturian Substage and is one of the indices for the base of the Crenulopteris acadica Zone (Wagner 1984; Cleal 1991; Cleal and Thomas 1994). However, Wagner (1968) had previously stated that the slender pinnule form, which he called A. ambigua, could also range down into the Bolsovian Substage. An examination of his list of occurrences shows that this is mainly based on specimens from Saar-Lorraine Basin documented by Bertrand (1932, pl. 37, Fig. 1; pls. 38, 39; pl. 40, Fig. 2, pl. 41; pl. 42, Figs. 1, 2); other examples were subsequently figured by Laveine (1989, pls. 18, 19, Fig. 2). These specimens have very similar shaped pinnules to A. grandinii except that the squatter, barrel-shaped forms are perhaps even rarer, but Bertrand's figured specimens appear to have more finely-marked, and more widely forking lateral veins, that can tend towards being flexuous.

These differences on the face of it may appear to be relatively subtle and be merely due to taphonomy: for instance, the apparent width of the veins can be influenced by whether the abaxial or adaxial surface of the pinnule is being examined. However, when the extensive collections of plant fossils from Saar-Loraine Basin in the University of Lille and the Saarbrücken Mining School were examined, a consistent pattern emerged: specimens from above Tonstein 60 in the Heiligenwald 

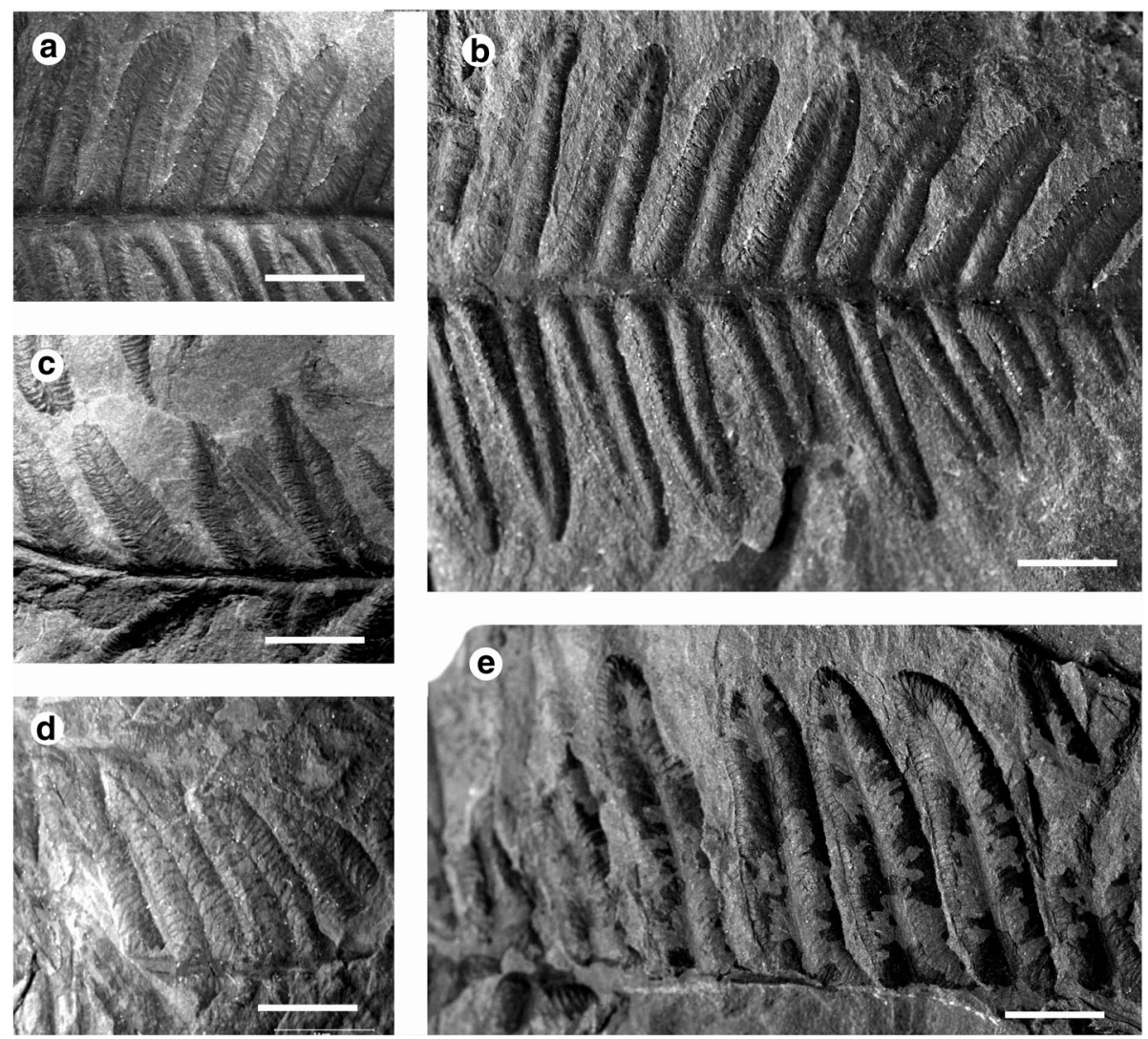

Fig. 5 Alethopteris grandinii (Brongniart) Göppert var. duboisii Bertrand; range of different pinnule morphologies, but all showing fine, somewhat flexuous veining; all scales bars $=5 \mathrm{~mm}$. a, b - Lower Heiligenwald Formation (lower Asturian Substage), Créhange 1 Borehole (depth 1799.6 m), (USTL 3193$)$ ); c Lower Heiligenwald Formation (lower Asturian Substage), Hallering 1 Borehole (depth 1341.5 m), (USTL 3194); d - Lower Heiligenwald Formation (lower Asturian Substage), Tritteling Borehole (depth 1041.0 m), (USTL 3195); e - Seam 5, Sulzbach Formation (Bolsovian Substage), Jägersfreude Mine, Saarland, (USTL 3196)

Formation were of the typical $A$. grandinii variety with narrowly forking veins, and all those from lower stratigraphical levels had the widely forking to flexuous veining pattern.

Among the specimens figured by Bertrand (1932, pl. 45) one was interpreted by him as sufficiently different from typical $A$. grandinii to merit distinction as a separate variety; $A$. grandinii var. duboisii Bertrand. The specimen originated from a horizon on the Sulzbach Formation and thus of Bolsovian age. Bertrand distinguished this specimen from typical $A$. grandinii by the wider spacing of the pinnae, but this is a very variable feature in such fronds. More significantly, however, the lateral veins are thinner and more widely forking, almost tending to being flexuous. This would therefore appear to correspond with the plant fossils we have observed in the Sulzbach, Luisenthal and lower Heiligenwald formations in Saar-Lorraine Basin - the early form of A. grandinii.

It is perhaps a debatable point as to whether Bertrand's trinomial, varietal nomenclature should be used, or whether it would be better to interpret this early form of
A. grandinii as a separate species and give it the name "duboisii". However, as the range of pinnule forms in the two taxa are almost identical, and the characteristic venation needed to distinguish them can sometimes be difficultly found in isolated specimens, we have opted to keep the taxonomic distinction at the varietal rank.

Other examples showing this type of venation were included by Bertrand (1932, pl. 37, Fig. 1; pls. 38, 39; pls. 40, 41; pl. 42, Figs. 1, 2).

\subsubsection{Occurrences}

Only known from the Saar-Lorraine Basin. Saarland, Sulzbach Formation: Flöz 13 (König, Helene and Friedrichsthal mines), Flöz 10 (Helene and Maybach mines), Flöz 9 (Velsen Mine), Flöz 7, 6 and 1 (unknown localities), Flöz 5 (Jägersfreude Mine; Bertrand 1932), Flöz 4 (Heinitz and Maybach Mines), Flöz 3 (König, Camphausen and Reden Mines), Flöz 1 (Frankenholz Mine; Bertrand 1932), Borehole Marianau 1 (depths 920.3 m, 690.9 m, 691.2 m, 691.3 $\mathrm{m}$ and $691.5 \mathrm{~m}$ ), Borehole Papiermühle (depth $419.1 \mathrm{~m}$ ) and Borehole Stocken (depths $1097.5 \mathrm{~m}, 1233.0 \mathrm{~m}, 1233.3$ $\mathrm{m}$ and $1314.8 \mathrm{~m}$ ). Saarland, Luisenthal Formation: 0.80 Flöz 
(Reden Mine), Flöz IIR (Helene Mine), Flöz Kallenberg (Reden Mine). Saarland, Lower Heiligenwald Formation: Flöz Polly 1 (Kohlwald Mine). Lorraine, lower "Assise" Flambants: Pit V, Merlebach (Veine 5 and 16; Bertrand 1932), Borehole Chasseurs (depths 656.5 m, 794.0 m, 825.6 $\mathrm{m}$ and $910.4 \mathrm{~m}$ ), Borehole Créhange 1 (depths $1799.4 \mathrm{~m}$ and $1799.6 \mathrm{~m}$ ), Borehole Fockloch (depth $535.4 \mathrm{~m}$ ), Borehole Folschviller 23 (depth $15.8 \mathrm{~m}$ ), Borehole Hallering (depth $1341.5 \mathrm{~m}$ ), Borehole Merbette (depths $1007.9 \mathrm{~m}$ and $1007.9 \mathrm{~m}$ ), Borehole Merlebach (depth $278.6 \mathrm{~m}$ ), Borehole Oratoire (depth 808.9 m), Borehole Simon 21 (depth 297.1 $\mathrm{m}$ ), Borehole St Fontaine 1 (depths 709.8 m, 781.8 m, 933.5 m, 940.9 m, $956.7 \mathrm{~m}$ and $1051.4 \mathrm{~m}$ ), Borehole St Fontaine 2 (depths $509.8 \mathrm{~m}, 1038.4 \mathrm{~m}$ and $1049.6 \mathrm{~m}$ ), Borehole St Fontaine 4 (depths $942.4 \mathrm{~m}, 976.9 \mathrm{~m}, 1086.1 \mathrm{~m}, 1086.1 \mathrm{~m}$ and $1098.4 \mathrm{~m}$ ), Borehole St Fontaine 6 (depth $1103.5 \mathrm{~m}$ ) and Borehole Tritteling (depths $1044.8 \mathrm{~m}, 1079.5 \mathrm{~m}, 1102.0$ $\mathrm{m}, 1102.2 \mathrm{~m}$ and $1102.3 \mathrm{~m})$.

\section{Discussion}

The base of the Crenulopteris acadica Zone in Variscan Euramerica represented a major change in the vegetation in Variscan Euramerica during Westphalian times, marked by a significant increase in abundance and diversity in the adpression floras of alethopterid medullosaleans and marattialean ferns. It was probably related to the diachronous change from lycopsid- to marattialeandominated vegetation in the peat-substrate vegetation (as reflected in the coal ball and palynological record) that seems to have occurred in mid-Westphalian times in eastern Variscan Euramerica, late Westphalian times in western Euramerica and early Stephanian times in west of the Acadian Mountains (Gastaldo et al. 1996, Cleal et al. 2010a, 2011). This change has been variously interpreted as due to climate change (e.g. DiMichele et al. 1985; DiMichele and Phillips 1996; Pfefferkorn et al. 2008), landscape change due to Variscan tectonics (Cleal and Thomas 1999) or a combination of the two (Cleal et al. 2010a, 2011). However, understanding this vegetational change also requires some understanding of where these species came from: did they evolve within the coal swamps or is the apparent change the result of plant migration?

The evidence reviewed in this paper indicates that at least one of the alethopterid species that appears at this level in the lowland basins (A. grandinii) may have originated in the upland wetlands of Saar-Lorraine, first appearing there some 4 million years earlier, based on the chronology of Opluštil et al. (2016). Care must be taken not to draw too many conclusions; we are after all dealing with fossil-taxa of foliage and not taxa of whole organisms. However, these frond fragments found in the earlier Saar-Lorraine floras have virtually indistinguishable pinnule shapes and epidermal structure to the later forms, and only differ in relatively subtle aspects of the venation; hence they are only separated taxonomically at the rank of variety.

This may not be the only example of Westphalian age plants appearing earlier in intra-montane basins than in paralic areas. A. grandinii does not occur in the other major late Westphalian intramontane basin (the West and Central Bohemia Basin) but in the upper Asturian-lower Cantabrian Nýrany Member there are abundant remains of another of the species associated with the base of the Crenulopteris acadica Zone: Alethopteris pseudograndinioides Zodrow and Cleal (Šimůnek 1988). However, there has also recently been a record of a fragment of foliage in the early Bolsovian Radnice Member that closely resembles A. pseudograndinioides (Šimůnek and Cleal, 2018), also suggesting that the alethopterids associated with the mid-Asturian floral change may have originated in upland wetland habitats. A similar suggestion has also been made by Thomas (1997, p. 149) for anisophyllous herbaceous lycopsids, which first appeared in intra-montane basins in Bolsovian aged floras, and do not occur in the lowland paralic basins until late Asturian times.

In stratigraphically earlier floras there are also indications of upland-lowland migration of species. Laveineopteris bohemica (von Ettingshausen) Šimůnek (= "Neuropteris" nicolausiana Gothan) found in lower Bolsovian floras of both Saar-Lorraine and West and Central Bohemia (Bertrand 1930; Šimůnek and Cleal 2011, 2013) is morphologically similar to Laveineopteris rarinervis (Bunbury) Cleal et al., 1990 from the upper Bolsovian and younger floras of the lowland and paralic parts of Variscan Euramerica (e.g. Laveine 1967; Cleal 2007). In the upper Duckmantian part of the Radnice Member of the West and Central Bohemia Basin there are sphenophytes recorded as Annularia longifolia Brongniart (e.g. von Ettingshausen 1854) that look remarkably similar (albeit a little larger) to Annularia spinulosa von Sternberg, which does not normally appear in the lowland basins until the upper part of the Duckmantian Substage (e.g. Cleal 2007).

We know of few examples of the reverse, lowland to upland migration of species. The only possible exception is Laveinopteris tenuifolia (von Sternberg) Cleal et al., which in the lowland basins ranges from the lower Langsettian through to the basal Asturian substages, but in the Saar-Lorraine sequences does not appear until the Bolsovian Subtage (e.g. Bertrand 1930; Laveine 1989); it is so-far unrecorded from West and Central Bohemia (Šimůnek and Cleal, 2011).

\section{Conclusions}

The medullosan pteridosperms that bore Alethopteris grandinii (= A. ambigua auct.) and possibly Alethopteris pseudograndinioides fronds occurred in the upland 
wetland basins of Variscan Euramerica in early Bolsovian times, and only migrated into the lowland wetlands in middle Asturian times, some 4 million years later. An explanation for this migration will require further investigation. The vegetation change represented by the base of the Crenulopteris acadica Zone has been linked with landscape and climatic changes possibly resulting in better-drained substrates (e.g. Cleal et al. 2010a), although the continued development of coal deposits indicates we are still dealing with wetland habitats. Perhaps there was some aspect of these upland wetlands that pre-adapted some plants to conditions in the changed environments of the lowlands. Especially in the West and Central Bohemia Basin, we now have considerable data on the middle Westphalian vegetation and ecology of the peat substrate habitats through the work on the in situ floras found in the Whetstone Horizon, an ash-band within the Radnice Coal Seam (e.g. Opluštil et al. 2007, 2009, 2014; Libertín et al. 2009). However, the ecological relationship between this vegetation and the clastic substrate vegetation preferentially preserved in the adpression floras is still uncertain (Opluštil et al. 2007, 2014). It has been suggested that the clastic substrates between the coals of the Radnice Member tend to be relatively coarse (Opluštil and Pešek 1998; Opluštil et al. 1999) suggesting they may have been somewhat better drained than those of lowland clastic substrate habitats; but whether this would have been sufficient to pre-adapt some of the upland plant species to the changed, post middle Asturian conditions in the lowlands is uncertain. No comparable data are so far available from Saar-Lorraine. With the alethopterids, maybe the large size of the ovules (e.g. Cleal et al. 2010b) may have favoured upland to lowland migration due to purely gravitational factors. Whatever the explanation, it is clear that a better understanding of the ecological relationships between the upland and lowland wetland habitats of Variscan Euramerica will be critical for a proper understanding of coal swamp vegetational dynamics.

\section{Abbreviations}

auct.: auctorum (of other authors); emend:: emended; ft: feet (as in imperial scale measurements); Ibid.: Ibidem (in the same place); nov. emend: new emendation; std.: standard deviation

\section{Acknowledgements}

The authors thank Ms. Jessie Cuvelier (University of Lille) for substantial help in collating the stratigraphical data from the Lorraine Coalfield used in this paper; also the late Prof. G. Kneuper and the late Herr B.-A. Richter for help during research in Saarbrücken; and also the late Prof. R.H. Wagner (formerly of Sheffield University) for valuable help on alethopterid taxonomy.

\section{Funding}

Part of the work by CJC on the Saarland floras was supported by the Deutsche Forschungsgeneinschaft. Thanks also go to the Université de Lille (University of Lille) for support through their "Conférencier étranger" scheme.

\section{Availability of data and materials}

This study was based on the palaeontological collections of the University of Lille and of the Zentrum für Biodokumentation in Landsweiler-Reden, Saarland (formerly of the Saarbrücken Mining School, stored at Von der Heydt).

\section{Authors' contributions}

Collation of the Saarland data and the initial taxonomic analysis was by CJC. Collation of the data from Lorraine was through collaboration between both authors (with the assistance of Ms. Jessie Cuvelier). The writing of the final manuscript was also through collaboration between both authors. Both authors read and approved the final manuscript.

\section{Competing interests}

The authors declare that they have no competing interests.

\section{Publisher's Note}

Springer Nature remains neutral with regard to jurisdictional claims in published maps and institutional affiliations.

\section{Author details}

${ }^{1}$ Department of Natural Sciences, National Museum Wales, Cardiff CF10 3NP, UK. ${ }^{2}$ CNRS, University of Lille, UMR 8198 - Evo-Eco-Paleo, F-59000 Lille, France.

Received: 3 October 2018 Accepted: 6 March 2019

Published online: 01 April 2019

\section{References}

Barthel, M. 1962. Epidermisuntersuchungen an einigen inkohlten Pteridospermenblättern des Oberkarbons und Perms. Geologie 11: 1-140.

Becq-Giraudon, J.F., C. Montenat, and J. Van Den Driessche. 1996. Hercynian highaltitude phenomena in the French massif central: Tectonic implications. Palaeogeography, Palaeoclimatology, Palaeoecology 122: 227-241.

Becq-Giraudon, J.F., and J. Van Den Driessche. 1994. Dépots peri-glaciaires dans le Stéphano-Autunien du Massif Central: témoin de l'effondrement gravitaire d'un haut-plateau hercynien. Comptes Rendus de l'Académie des Sciences de Paris 318: 675-683.

Bertrand, P. 1930. Bassin houiller de la Sarre et de la Lorraine. I. Flore fossile. let Fascicule Neuroptéridées. Lille: Mines Domaniales Françaises de la Sarre (Études des Gîtes Minéraux de la France).

Bertrand, P. 1932. Bassin houiller de la Sarre et de la Lorraine. I. Flore fossile. 2 me Fascicule. Aléthoptéridées. Lille: Mines Domaniales Françaises de la Sarre (Études des Gîtes Minéraux de la France).

Blake, B.M., A.T. Cross, C.F. Eble, W.H. Gillespie, and H.W. Pfefferkorn. 2002. Selected plant megafossils from the Carboniferous of the Appalachian Region, eastern United States: geographic and stratigraphic distribution. In Carboniferous and Permian of the world. Proceedings of the XIV International Congress on Carboniferous and Permian stratigraphy, Calgary, Alberta, Canada August 17-21, 1999, ed. L.V. Hills, C.M. Henderson, and E.W. Bamber, 259-335. Calgary: Canadian Society of Petroleum Geologists (Memoirs, 19).

Bless, M.J.M., J. Bouckert, M.A. Calver, J.M. Graulich, and E. Paproth. 1977. Paleogeography of upper Westphalian deposits in NW Europe with reference to the Westphalian $\mathrm{C}$ north of the mobile Variscan belt. Mededelingen Rijks Geologische Dienst, Nieuwe Serie 28: 101-147.

Bless, M.J.M., M.A. Calver, and K.-H. Josten. 1972. Report of the working group on the Westphalian C in N.W. Europe. Compte rendu 7e Congrès International de Stratigraphie et de Géologie du Carbonifère 1: 223-230.

Bless, M.J.M., and C.F. Winkler Prins. 1972. Paleoecology and paleogeography of the Aegir marine band and its equivalents in North-Western Europe. Compte rendu 7 e Congrès International de Stratigraphie et de Géologie du Carbonifère 1: 231-239.

Bouroz, A. 1967. Corrélation des tonsteins d'origine volcanique entre les bassins houillers de Sarro-Lorraine et du Nord-Pas-de-Calais. Comptes Rendus Hebdomadaires des Seances de l'Academie des Sciences, Serie D 264: 2729-2732.

Brongniart, A. 1833. Histoire des végétaux fossiles, Vol. 1(7). Paris: G. Dufour and E. d'Ocagne.

Buisine, M. 1961. Contribution a l'étude de la flore du terrain houiller. Les Aléthoptéridées du Nord de la France. Lille: Houillères du Bassin du Nord et du Pas-de-Calais (Études Géologiques pour l'Atlas Topographie Souterraine). 
Cleal, C.J. 1978. Floral biostratigraphy of the upper Silesian pennant measures of South Wales. Geological Journal 13: 165-194.

Cleal, C.J. 1984. The Westphalian D floral biostratigraphy of Saarland (Fed. Rep. Germany) and a comparison with that of South Wales. Geological Journal 19: 327-351.

Cleal, C.J. 1991. Carboniferous and Permian biostratigraphy. In Plant fossils in geological investigation: The Palaeozoic, ed. C.J. Cleal, 182-215. Chichester: Ellis Horwood.

Cleal, C.J. 2005. The Westphalian macrofloral record from the cratonic central Pennines Basin, UK. Zeitschrift der Deutschen Gesellschaft für Geowissenschaften 156: 387-410

Cleal, C.J. 2007. The Westphalian-Stephanian macrofloral record from the South Wales coalfield. Geological Magazine 144: 465-486.

Cleal, C.J. 2008a. Palaeofloristics of middle Pennsylvanian lyginopteridaleans in Variscan Euramerica. Palaeogeography, Palaeoclimatology, Palaeoecology 261: 1-14

Cleal, C.J. 2008b. Palaeofloristics of middle Pennsylvanian medullosaleans in Variscan Euramerica. Palaeogeography, Palaeoclimatology, Palaeoecology 268 $164-180$.

Cleal, C.J. 2008c. Westphalian-Stephanian macrofloras of the southern Pennines Basin, UK. Studia Geologica Polonica 129: 25-41.

Cleal, C.J. 2018. The Carboniferous coal swamp floras of England: A window on an ancient tropical ecosystem. Proceedings of the Geologists' Association 129: 329-351.

Cleal, C.J., S. Opluštil, B.A. Thomas, and Y. Tenchov. 2010a. Late Moscovian terrestrial biotas and palaeoenvironments of Variscan Euramerica. Netherlands Journal of Geosciences 88: 181-278.

Cleal, C.J., S. Opluštil, B.A. Thomas, and Y. Tenchov. 2011. Late Moscovian terrestrial biotas and palaeoenvironments of Variscan Euramerica. Pennsylvanian vegetation and climate in tropical Variscan Euramerica. Episodes 34: 3-12.

Cleal, C.J., C.H. Shute, and E.L. Zodrow. 1990. A revised taxonomy for Palaeozoic neuropterid foliage. Taxon 39: 486-492.

Cleal, C.J., and B.A. Thomas. 1994. Plant fossils of the British Coal Measures. London: Palaeontological association (field guide to fossils 6).

Cleal, C.J., and B.A. Thomas. 1999. Tectonics, tropical forest destruction and global warming in the late Palaeozoic. Acta Palaeobotanica, Supplement 2: 17-19.

Cleal, C.J., and B.A. Thomas. 2005. Palaeozoic tropical rainforests and their effect on global climates: Is the past the key to the present? Geobiology 3: 13-31.

Cleal, C.J., D. Uhl, B. Cascales-Miñana, B.A. Thomas, A.R. Bashforth, S.C. King, and E. L. Zodrow. 2012. Plant biodiversity changes in carboniferous tropical wetlands. Earth-Science Reviews 114: 124-155.

Cleal, C.J., E.L. Zodrow, and M. Mastalerz. 2010b. An association of Alethopteris foliage, Trigonocarpus ovules and Bernaultia-like pollen organs from the middle Pennsylvanian of Nova Scotia, Canada. Palaeontographica Abteilung B 283: 73-97.

DiMichele, W.A., and T.L. Phillips. 1996. Climate change, plant extinction and vegetational recovery during middle-late Pennsylvanian transition: The case of tropical peat-forming environments in North America. In Biotic recovery from mass extinction events, ed. M. Hart, 201-221. London: Geological Society.

DiMichele, W.A., T.L. Phillips, and R.A. Peppers. 1985. The influence of climate and depositional environment on the distribution and evolution of Pennsylvanian coal swamp plants. In Geological factors in the evolution of plants, ed. B. Tiffney, 223-256. New Haven CT: Yale University Press.

Gastaldo, R.A., W.A. DiMichele, and H.W. Pfefferkorn. 1996. Out of the icehouse into the greenhouse: A late Paleozoic analog for modern global vegetational change. GSA Today 6: 1-7.

Göppert, H. 1836. Systema filicum fossilium. Nova acta physico-medica Academiae Caesareae Leopoldino-Carolinae Naturae Curiosum 9 (Suppl. 17): 1-486.

Gothan, W. 1915. Pflanzengeographisches aus der paläozoischen Flora mit Ausblicken auf die mesozoischen Folgefloren. Englers Botanische Jahrbücher 52: $221-271$

Gothan, W. 1925. Gemeinsame Züge und Verschiedenheiten in den Profilen des Karbons der paralischen und limnischen (Binnen-)Kohlenbecken. Zeitschrift der Deutschen Geologischen Gesellschaft 77: 391-404

Gothan, W. 1951. Die merkwürdigen pflanzengeographischen Besonderheiten in den mitteleuropäischen Karbonfloren. Palaeontographica Abteilung B 91: 109-130.

Gothan, W. 1954. Pflanzengeographisches aus dem mitteleuropäischen Karbon. Geologie 3: 219-257.
Holub, V., V. Skoček, and R. Tasler. 1977. Palaeogeographical analysis of the Permo-carboniferous in the bohemian massif. In Symposium on carboniferous stratigraphy, ed. V.M. Holub and R.H. Wagner, 441-457. Praque: Geological Survey.

Jongmans, W.J. 1955. Notes paléobotaniques sur les Bassins houillers de I'Anatolie. Mededelingen van de Geologische Stichting, Serie C 9: 55-89.

Kneuper, G. 1964. Grundzüge der Sedimentation und Tektonik im Oberkarbon des Saarbrücker Hauptsattels. Oberrheinische Geologische Abhandlungen 13: 1-49.

Kneuper, G. 1966. Zur Entstehung und Entwicklung der Saar-Nahe-Senke. Zeitschrift des deutsche geologische Gesellschaft 117: 312-322.

Korsch, R.J., and A. Schäfer. 1995. The Permo-carboniferous Saar-Nahe Basin, south-West Germany and north-East France: Basin formation and deformation in a strike-slip regime. International Journal of Earth Sciences 84: 293-318.

Laveine, J.P. 1967. Contribution a l'étude de la flore du terrain houiller. Les Neuroptéridées du Nord de la France. Lille: Houillères du Bassin du Nord et du Pas-de-Calais (Études Géologiques pour l'Atlas Topographie Souterraine, 1, 5).

Laveine, J.P. 1977. Report on the Westphalian D. In Symposium on carboniferous stratigraphy, ed. V.M. Holub and R.H. Wagner, 71-83. Ptague: Geological Survey.

Laveine, J.P. 1989. Guide paléobotanique dans le terrain houiller Sarro-Lorrain. Merlebach: Houillères du Bassin de Lorraine.

Lesquereux, L. 1879. Atlas to the Coal Flora of Pennsylvania, and the Carboniferous formation throughout the United States, 1-2. Harrisburg PA: Second Geological Survey of Pennsylvania (Report of Progress).

Libertín, M., S. Opluštil, J. Pšenička, J. Bek, I. Sýkarová, and J. Daškova. 2009. Middle Pennsylvanian pioneer plant assemblage buried in situ by volcanic ash-fall, Central Bohemia, Czech Republic. Review of Palaeobotany and Palynology 155: 204-233.

Opluštil, S. 2005. Evolution of the middle Westphalian river valley drainage system in Central Bohemia (Czech Republic) and its palaeogeographic implication. Palaeogeography, Palaeoclimatology, Palaeoecology 222: 223-258.

Opluštil, S., and C.J. Cleal. 2007. A comparative analysis of some late Carboniferous basins of Variscan Europe. Geological Magazine 144: 417-448.

Opluštil, S., and J. Pešek. 1998. Stratigraphy, palaeoclimatology and palaeogeography of the late Palaeozoic continental deposits in the Czech Republic. Geodiversitas 20: 597-620.

Opluštil, S., J. Pšenička, J. Bek, J. Wang, Z. Feng, M. Libertín, Z. Šimůnek, J. Bureš, and J. Drábková. 2014. T peat-forming plant assemblage preserved in growth position by volcanic ash-fall: A case study from the middle Pennsylvanian of the Czech Republic. Bulletin of Geosciences 89: 773-818.

Opluštil, S., J. Pšenička, M. Libertín, A. Bashforth, and Z. Šimůnek. 2009. A middle Pennsylvanian (Bolsovian) peat-forming forest preserved in situ in volcanic ash of the whetstone horizon in the Radnice Basin, Czech Republic. Review of Palaeobotany and Palynology 155: 234-274.

Opluštil, S., J. Pšenička, M. Libertín, and Z. Šimůnek. 2007. Vegetation patterns of Westphalian and lower Stephanian mire assemblages preserved in tuff beds of the continental basins of Czech Republic. Review of Palaeobotany and Palynology 143 107-154.

Opluštil, S., M. Schmitz, C.J. Cleal, and K. Martínek. 2016. A review of the middlelate Pennsylvanian west European regional substages and floral biozones, and their correlation to the geological time scale based on new U-Pb ages. Earth-Science Reviews 154: 301-335.

Opluštil, S., I. Sýkorová, and J. Bek. 1999. Sedimentology, coal petrography and palynology of the Radnice member in the S-E part of the Kladno-Rakovník Basin, Central Bohemia. Acta Universitatis Carolinae, Geologica 43: 599-623.

Pfefferkorn, H.W., R.A. Gastaldo, W.A. DiMichele, and T.L. Phillips. 2008 Pennsylvanian tropical floras from the United States as a record of changing climate. In Resolving the Late Paleozoic Ice Age in Time and Space, ed. C.R. Fielding, T.D. Frank, and J.L. Isbell, 305-316. Boulder Co.: Geological Society of America (Special Paper, 441).

Pfefferkorn, H.W., and W.H. Gillespie. 1980. Biostratigraphy and biogeography of plant compression fossils in the Pennsylvanian of North America. In Biostratigraphy of Fossil Plants, ed. D.L. Dilcher and T.N. Taylor, 93-118. Stroudsburg PA: Dowden, Hutchinson and Ross.

Potonié, H. 1893. Die Flora des Rothliegenden von Thüringen. Abhandlungen der Königlich Preussischen Geologischen Landesanstalt, Neue Folge 9 (2): 1-298. 
Schäfer, A., and R.J. Korsch. 1998. Formation and sediment fill of the Saar-Nahe basin (Permo-carboniferous, Germany). Zeitschrift der Deutschen Geologischen Gesellschaft 149: 233-269.

Schindler, T., and V.H. Heidtke. 2007. Kohlsümpfe, Seen und Halbwüsten. In Dokumente einer rund 300 Millionen Jahre alten Lebewelt zwischen Saarbrücken und Mainz. Neustadt an der Weinstraße: Pollichia.

Schlotheim, E.F. 1820. Die Petrefactenkunde auf ihrem jetzigen Standpunkte durch die Beschreibung seiner Sammlung versteinerter und fossiler Überreste des Thierund Pflanzenreichs der Vorwelt erläutert. Gotha: Becker'sche Buchhandlung.

Šimůnek, Z. 1988. Varieties of the species Alethopteris grandinioides Kessler from the Kladno formation (Westphalian C, D, Bohemia). Casopis pro mineralogii a geologii 33: 381-394.

Šimůnek, Z, and CJ. Cleal. 2011. Imparipinnate neuropteroid foliage (Medullosales) from the middle Westphalian of the west and Central Bohemia Coal Basin, Czech Republic. Review of Palaeobotany and Palynology 166: 163-201.

Šimůnek, Z, and CJ. Cleal. 2013. The epidermis of cyclopteroid Laveineopteris bohemica (Medullosales) from the middle Pennsylvanian Radnice member, Czech Republic. Bulletin of Geosciences 88: 63-67.

Šimůnek, Z., and C.J. Cleal. 2018. Early occurrence of a Pennsylvanian-age medullosalean frond similar to Alethopteris pseudograndinioides in the intramontane basin of Bohemia. Fossil Imprint 74: 37-44.

Tenchov, Y.G. 1976. Composition peculiarities of the Carboniferous flora of the Svoge Basin, West Bulgaria. Geologica Balcanica 6: 3-11.

Tenchov, Y.G. 1977. Flora und Biostratigraphie des Oberkarbons im Svoge-Becken (VR Bulgarien). Schriftenreihe fur Geologische Wissenschaften 7: 1-163.

Thomas, B.A. 1997. Upper Carboniferous herbaceous lycopsids. Review of Palaeobotany and Palynology 95: 129-153.

Thomas, B.A. 2007. Phytogeography of Asturian (Westphalian D) lycophytes throughout the Euramerican belt of coalfields. Geological Magazine 144: $457-$ 463.

Thomas, B.A., and C.J. Cleal. 1994. Plant fossils from the Writhlington geological nature reserve. Proceedings of the Geologists' Association 105: 15-32.

Thomas, B.A., and C.J. Cleal. 2017. Distinguishing Pennsylvanian-age lowland, extra-basinal and upland vegetation. Palaeobiodiversity and Palaeoenvironments 97 (2): 273-293.

Uhl, D., and C.J. Cleal. 2010. Late Carboniferous vegetation change in lowland and intramontane basins. International Journal of Coal Geology 83: 318-328.

von Ettingshausen, C. 1854. Die Steinkohlenflora von Radnitz in Böhmen. Vienna: Kaiserlich königliche geologische Reichsanstalt, Abhandlungen, 2, Part 3.

von Sternberg, K.M. 1825. Versuch einer geognostisch-botanischen Darstellung der Flora der Vorwelt. Volume 1, Part 4, Tentamen. Regensburg: E. Brenck's Wittwe.

Wagner, R.H. 1968. Upper Westphalian and Stephanian species of Alethopteris from Europe, Asia Minor and North America. Mededelingen van de Rijks Geologische Dienst, Serie C, III-1 6: 1-188.

Wagner, R.H. 1974. The chronostratigraphic units of the upper Carboniferous in Europe. Bulletin de la Société Belge de Géologie, de Paléontologie et d'Hydrologie 83: 235-253.

Wagner, R.H. 1984. Megafloral zones of the carboniferous. Compte rendu 9e Congrès international de Stratigraphie et de Géologie du Carbonifère (Washington, 1979) 2: 109-134

Wagner, R.H., L.C. Sánchez de Posada, M.L. Martínez Chacón, L.P. Fernández, E. Villa, and C.F. Winkler Prins. 2002. The Asturian Stage: a preliminary proposal for the definition of a substitute for Westphalian D. In Carboniferous and Permian of the World: XIV ICCP Proceedings, ed. L.V. Hills, C.M. Henderson, and E.W. Bamber, 832-850. Calgary: Canadian Society of Petroleum Geologists (Memoirs, 19).

Wagner, R.H., and C.F. Winkler Prins. 2016. History and current status of the Pennsylvanian chronostratigraphic units: Problems of definition and interregional correlation. Newsletters on Stratigraphy 49: 281-320.

Wittry, J. 2006. The Mazon Creek fossil flora. Downers Grove: Esconi Associates.

Wittry, J., IJ. Glasspool, O. Béthoux, R. Koll, and CJ. Cleal. 2015. A revision of the Pennsylvanian marattialean fern Lobatopteris vestita auct. And related species. Journal of Systematic Palaeontology 13: 615-643.

Zodrow, E.L. 1990. Revision and emendation of Pecopteris arborescens group, Permo-carboniferous. Palaeontographica Abteilung B 217: 1-49.

Zodrow, E.L., and C.J. Cleal. 1998. Revision of the pteridosperm foliage Alethopteris and Lonchopteridium (upper Carboniferous), Sydney coalfield, Nova Scotia, Canada. Palaeontographica Abteilung B 247: 65-122.

Zodrow, E.L., Z. Šimůnek, C.J. Cleal, J. Bek, and J. Pšenička. 2006. Taxonomic revision of the Palaeozoic marattialean fern Acitheca. Review of Palaeobotany and Palynology 138: 239-280.

\section{Submit your manuscript to a SpringerOpen ${ }^{\circ}$ journal and benefit from:}

- Convenient online submission

- Rigorous peer review

- Open access: articles freely available online

- High visibility within the field

- Retaining the copyright to your article

Submit your next manuscript at $\boldsymbol{\nabla}$ springeropen.com 